\title{
The yielding and weed infestation of blue lupine mixtures with oat cultivated for green mass
}

\section{Plonowanie a zachwaszczenie mieszanek łubinu wąskolistnego z owsem uprawianych na zieloną masę}

\author{
Anna Płaza*, Artur Makarewicz, Barbara Gąsiorowska, \\ Anna Cybulska, Rafał Górski, Emilia Rzążewska
}

\begin{abstract}
Summary
The paper presents the results from the studies carried our in 2009-2011. The objective of the research was to evaluate the influence of the share of components in the mixtures of blue lupine and oat, and the harvest date on the yield, and weed infestation. Two factors were taken into account: I - the share of components in the mixture: blue lupine (pure stand) 100\%, oat (pure stand) $100 \%$, blue lupine $75 \%$ + oat $25 \%$, blue lupine $50 \%$ + oat $50 \%$, blue lupine $25 \%+$ oat $75 \%$, II - the harvest date: flowering stage of blue lupine, flat green pod stage of blue lupine. The results showed that the blue lupine and oat mixtures were less infested with weeds than blue lupine cultivated in a pure stand. The less mass of weed was observed in the mixtures that were harvested at the flowering stage of blue lupine than at the flat green pod stage of blue lupine. The highest yield of green matter was obtained from the blue lupine and oat mixture with the share of components $50 \%+50 \%$ and the oat cultivated in a pure stand, and harvested at the flat green pod stage of blue lupine.
\end{abstract}

Key words: mixture; blue lupine; oat; weed; yield

\section{Streszczenie}

W pracy przedstawiono wyniki badań z lat 2009-2011 mające na celu określenie wpływu udziału komponentów w mieszance i terminu zbioru na plonowanie oraz zachwaszczenie mieszanek łubinu wąskolistnego z owsem. W doświadczeniu badano dwa czynniki: I - udział komponentów w mieszance: łubin wąskolistny (siew czysty) $100 \%$, owies (siew czysty) $100 \%$, łubin wąskolistny $75 \%$ + owies $25 \%$, łubin wąskolistny $50 \%$ + owies $50 \%$, łubin wąskolistny $25 \%$ + owies $75 \%$, II - termin zbioru: faza kwitnienia łubinu wąskolistnego, faza płaskiego zielonego strąka łubinu wąskolistnego. Otrzymane wyniki badań pozwalają stwierdzić, iż mieszanki łubinu wąskolistnego z owsem charakteryzowały się mniejszym zachwaszczeniem niż łubin wąskolistny uprawiany w siewie czystym. Mniejszą masę chwastów odnotowano w mieszankach zebranych w fazie kwitnienia niż w fazie płaskiego zielonego strąka łubinu wąskolistnego. Większy plon świeżej masy otrzymano z mieszanki łubinu wąskolistnego z owsem o udziale komponentów $50 \%+50 \%$ oraz z owsa uprawianego w siewie czystym zebranych w fazie płaskiego zielonego strąka łubinu wąskolistnego.

Słowa kluczowe: mieszanka; łubin wąskolistny; owies; zachwaszczenie; plon

\footnotetext{
Uniwersytet Przyrodniczo-Humanistyczny w Siedlcach

Wydział Przyrodniczy

Prusa 14, 08-110 Siedlce

*corresponding author: plaza@uph.edu.pl
} 


\section{Wstęp / Introduction}

Jedną z naturalnych i proekologicznych metod regulacji zachwaszczenia jest uprawa współrzędna roślin (Creamer i wsp. 1996; Idziak i Michalski 2003; Buczek i wsp. 2007; Sobkowicz i Podgórska-Lesiak 2007; Wojciechowski i wsp. 2013). W zasiewach mieszanych zaznacza się tendencja do redukcji zachwaszczenia. Wynika to z faktu, iż gatunki uprawiane $\mathrm{w}$ mieszankach wzajemnie uzupełniają nisze ekologiczne $\mathrm{w}$ łanie. Dzięki temu, lepsze zwarcie łanu pozwala roślinom uprawnym skuteczniej konkurować z chwastami (Christensen 1995; Parylak i wsp. 2006; Buraczyńska 2009; Wojciechowski i wsp. 2013). Ten sposób walki z chwastami zmniejsza koszty odchwaszczania, a także powoduje brak ryzyka zanieczyszczenia środowiska i produktów roślinnych pozostałościami substancji czynnych (Wanic i wsp. 2004; Buczek i wsp. 2007; Buraczyńska 2009).

Rośliny bobowate, w tym łubin wąskolistny, pomimo że spełniają założenia i warunki rolnictwa zrównoważonego są dość zawodne w plonowaniu. Dlatego też, aby wykorzystać potencjał hodowlany gatunków roślin bobowatych należy poszukiwać rozwiązań, które umożliwiłyby stabilizację poziomu plonowania i redukcji zachwaszczenia. Jednym $z$ takich rozwiązań jest uprawa międzygatunkowa roślin bobowatych ze zbożami (Wojciechowski i wsp. 2013). Zasiewy mieszane plonują zazwyczaj wierniej od czystych siewów gatunków będących komponentami mieszanek (Borowiecki i Księżak 2000).

Celem przeprowadzonych badań było określenie wpływu udziału komponentów w mieszance i terminu zbioru na zachwaszczenie i plonowanie mieszanek łubinu wąskolistnego $\mathrm{z}$ owsem.

\section{Materiały i metody / Materials and methods}

Badania polowe przeprowadzono w latach 2009-2011 w Rolniczej Stacji Doświadczalnej w Zawadach należącej do Uniwersytetu Przyrodniczo-Humanistycznego w Siedlcach. Badania prowadzono na glebie płowej. Gleba charakteryzowała się odczynem obojętnym, średnią zasobnością w przyswajalny fosfor, potas i magnez. Doświadczenie polowe założono w układzie split-blok, w trzech powtórzeniach. Badano dwa czynniki: I - udział komponentów w mieszance: łubin wąskolistny (siew czysty) $100 \%$, owies (siew czysty) 100\%, łubin wąskolistny $75 \%$ + owies $25 \%$, łubin wąskolistny $50 \%+$ owies $50 \%$, łubin wąskolistny $25 \%$ + owies $75 \%$, II - termin zbioru: faza kwitnienia łubinu wąskolistnego, faza płaskiego zielonego strąka łubinu wąskolistnego. Szczegółowy wykaz mieszanek i ich ilości wysiewu przedstawiał się następująco: łubin wąskolistny $200 \mathrm{~kg} / \mathrm{ha}$, owies $180 \mathrm{~kg} / \mathrm{ha}$, łubin wąskolistny $150 \mathrm{~kg} / \mathrm{ha}+$ owies $45 \mathrm{~kg} / \mathrm{ha}$, łubin wąskolistny $100 \mathrm{~kg} / \mathrm{ha}+$ owies $90 \mathrm{~kg} / \mathrm{ha}$, łubin wąskolistny $50 \mathrm{~kg} / \mathrm{ha}+$ owies $135 \mathrm{~kg} / \mathrm{ha}$. Jesienią stosowano nawozy fosforowo-potasowe w dawkach zależnych od zasobności gleby, tj. 35,2 kg/ha P i 99,6 kg/ha K. Wiosną przed siewem nasion stosowano nawożenie azotowe $\mathrm{w}$ dawce $30 \mathrm{~kg} / \mathrm{ha} \mathrm{N}$, na wszystkich obiektach z wyjątkiem łubinu wąskolistnego $\mathrm{W}$ siewie czystym. W fazie strzelania w źdźbło zastosowano dodatkowo $50 \mathrm{~kg} / \mathrm{ha} \mathrm{N}$ pod owies i $30 \mathrm{~kg} / \mathrm{ha} \mathrm{N}$ pod mieszanki owsa z łubinem wąskolistnym. Siew mieszanek łubinu wąskolistnego (odmiany Zeus) i owsa (odmiany Zuch) przeprowadzono w 1. dekadzie kwietnia. Zabiegi pielęgnacyjne polegały na dwukrotnym bronowaniu przed i raz po wschodach roślin broną średnią. Zbiór roślin przeprowadzono w 3. dekadzie czerwca (faza kwitnienia łubinu wąskolistnego) i w 1. dekadzie lipca (faza płaskiego zielonego strąka łubinu wąskolistnego). Tuż przed zbiorem mieszanek, $\mathrm{z}$ dwóch losowo wybranych miejsc każdego poletka, wyznaczonych ramką o wymiarach $1 \mathrm{~m} \times 0,5 \mathrm{~m}$ pobrano próby chwastów w celu oznaczenia ich liczby oraz świeżej i suchej masy. Natomiast podczas zbioru mieszanek łubinu wąskolistnego z owsem, na każdym poletku określono ich plon świeżej masy.

Każdą $\mathrm{z}$ badanych cech poddano analizie wariancji zgodnie ze schematem układu split-blok. W przypadku istotnych źródeł zmienności dokonano szczegółowego porównania średnich testem Tukeya.

\section{Wyniki i dyskusja / Results and discussion}

Świeża i sucha masa chwastów w łanie mieszanek łubinu wąskolistnego z owsem była istotnie różnicowana przez badane czynniki doświadczenia i ich interakcję (tab. 1, 2). Największą masę chwastów odnotowano w łanie łubinu wąskolistnego uprawianego w siewie czystym. Badania własne potwierdzają wcześniejsze wyniki opisane przez Christensen (1995), Buraczyńską (2009), Bojarczuka i wsp. (2013) oraz Wojciechowskiego i wsp. (2013). Autorzy ci wykazali, że siewy czyste roślin strączkowych charakteryzowały się największym zachwaszczeniem. W badaniach własnych dodatek rośliny zbożowej - owsa do łubinu wąskolistnego spowodował istotny spadek świeżej i suchej masy chwastów. Analogiczną zależność odnotowano w badaniach Creamer i wsp. (1996), Buraczyńskiej (2009), Wojciechowskiego i wsp. (2013) oraz Staniak i wsp. (2014). W omawianym doświadczeniu najmniejszą świeżą masę chwastów odnotowano w łanie owsa uprawianego w siewie czystym. Także Buraczyńska (2009) oraz Bojarczuk i wsp. (2013) wskazują na mniejszą podatność na zachwaszczenie zbóż uprawianych w czystym siewie. W badaniach własnych, spośród mieszanek najmniejszą masę chwastów odnotowano $\mathrm{w}$ łanie mieszanek łubinu wąskolistnego $\mathrm{z}$ owsem o udziale komponentów 25\% + 75\% oraz 50\% + 50\%. Istotnie wyższą masę chwastów odnotowano w łanie mieszanki łubinu wąskolistnego $\mathrm{z}$ owsem o udziale komponentów $75 \%+25 \%$. W tym przypadku także zachwaszczenie łanu mieszanki łubinu wąskolistnego $\mathrm{z}$ owsem było istotnie mniejsze niż łubinu wąskolistnego uprawianego w siewie czystym. Według doniesień literaturowych [Buczek i wsp. (2007); Sobkowicz i Podgórska-Lesiak (2007) oraz Buraczyńska (2009)] siewy mieszane mogą istotnie ograniczać zachwaszczenie. Idziak i Michalski (2003), Parylak i wsp. (2006) oraz Staniak i wsp. (2014) wykazali zmniejszenie zachwaszczenia łanów strączkowo-zbożowych poprzez dużą konkurencyjność roślin, co jest wynikiem lepszego zwarcia łanu oraz dokładniejszego 
Tabela 1. Świeża masa chwastów w łanie mieszanek łubinu wąskolistnego z owsem (średnie z lat 2009-2011) [g/m²]

Table 1. Fresh green matter of weeds in the mixtures of blue lupine and oat (average of the years 2009-2011) [g/m $\left.\mathrm{m}^{2}\right]$

\begin{tabular}{|c|c|c|c|}
\hline \multirow[b]{2}{*}{$\begin{array}{l}\text { Udział komponentów w mieszance } \\
\text { The share of components } \\
\text { in the mixture }\end{array}$} & \multicolumn{2}{|c|}{ Termin zbioru - The harvest date } & \multirow[b]{2}{*}{$\begin{array}{l}\text { Średnie } \\
\text { Means }\end{array}$} \\
\hline & $\begin{array}{c}\text { faza kwitnienia } \\
\text { łubinu wąskolistnego } \\
\text { flowering stage of blue lupine }\end{array}$ & $\begin{array}{l}\text { faza płaskiego zielonego strąka } \\
\text { łubinu wąskolistnego } \\
\text { flat green pod stage of blue lupine }\end{array}$ & \\
\hline $\begin{array}{l}\text { Łubin wąskolistny } 100 \% \\
\text { Blue lupine } 100 \%\end{array}$ & 95,8 & 128,4 & 112,1 \\
\hline Owies $100 \%$ - Oat $100 \%$ & 29,6 & 37,7 & 33,7 \\
\hline $\begin{array}{l}\text { Lubin wąskolistny } 75 \%+\text { owies } 25 \% \\
\text { Blue lupine } 75 \%+\text { oat } 25 \%\end{array}$ & 39,6 & 48,9 & 44,3 \\
\hline $\begin{array}{l}\text { Lubin wąskolistny } 50 \%+\text { owies } 50 \% \\
\text { Blue lupine } 50 \%+\text { oat } 50 \%\end{array}$ & 35,2 & 44,2 & 39,7 \\
\hline $\begin{array}{l}\text { Łubin wąskolistny } 25 \%+\text { owies } 75 \% \\
\text { Blue lupine } 25 \%+\text { oat } 75 \%\end{array}$ & 33,7 & 38,8 & 36,3 \\
\hline Średnie - Means & 46,8 & 59,6 & - \\
\hline \multicolumn{4}{|l|}{ NIR $(0,05)-\operatorname{LSD}(0.05)$} \\
\hline \multicolumn{3}{|c|}{ Udział komponentów w mieszance - The share of components in the mixture } & 3,5 \\
\hline \multicolumn{3}{|c|}{ Termin zbioru - The harvest date } & 1,8 \\
\hline \multicolumn{3}{|l|}{ Interakcja - Interaction } & 4,2 \\
\hline
\end{tabular}

Tabela 2. Powietrznie sucha masa chwastów w łanie mieszanek łubinu wąskolistnego z owsem (średnie z lat 2009-2011) [g/m²]

Table 2. The air-dry matter of weeds in the mixtures of blue lupine and oat (average of the years 2009-2011) $\left[\mathrm{g} / \mathrm{m}^{2}\right]$

\begin{tabular}{|c|c|c|c|}
\hline \multirow[b]{2}{*}{$\begin{array}{l}\text { Udział komponentów w mieszance } \\
\text { The share of components } \\
\text { in the mixture }\end{array}$} & \multicolumn{2}{|c|}{ Termin zbioru - The harvest date } & \multirow[b]{2}{*}{$\begin{array}{l}\text { Średnie } \\
\text { Means }\end{array}$} \\
\hline & $\begin{array}{l}\text { faza kwitnienia łubinu wąskolistnego } \\
\text { flowering stage of blue lupine }\end{array}$ & $\begin{array}{l}\text { faza płaskiego zielonego strąka } \\
\text { łubinu wąskolistnego } \\
\text { flat green pod stage of blue lupine }\end{array}$ & \\
\hline $\begin{array}{l}\text { Łubin wąskolistny } 100 \% \\
\text { Blue lupine } 100 \%\end{array}$ & 50,4 & 63,7 & 57,1 \\
\hline Owies $100 \%$ - Oat $100 \%$ & 13,4 & 18,2 & 15,9 \\
\hline $\begin{array}{l}\text { Łubin wąskolistny } 75 \%+\text { owies } 25 \% \\
\text { Blue lupine } 75 \% \text { + oat } 25 \%\end{array}$ & 20,1 & 25,7 & 24,6 \\
\hline $\begin{array}{l}\text { Łubin wąskolistny } 50 \%+\text { owies } 50 \% \\
\text { Blue lupine } 50 \%+\text { oat } 50 \%\end{array}$ & 17,4 & 23,8 & 21,6 \\
\hline $\begin{array}{l}\text { Łubin wąskolistny } 25 \%+\text { owies } 75 \% \\
\text { Blue lupine } 25 \% \text { + oat } 75 \%\end{array}$ & 16,1 & 23,5 & 19,8 \\
\hline Średnie - Means & 23,5 & 31,0 & - \\
\hline \multicolumn{4}{|l|}{ NIR $(0,05)-\operatorname{LSD}(0.05)$} \\
\hline \multicolumn{3}{|c|}{ Udział komponentów w mieszance - The share of components in the mixture } & 2,6 \\
\hline \multicolumn{3}{|l|}{ Termin zbioru - The harvest date } & 1,2 \\
\hline \multicolumn{3}{|l|}{ Interakcja - Interaction } & 3,2 \\
\hline
\end{tabular}

pokrycia gleby. W omawianym doświadczeniu termin zbioru także istotnie różnicował stopień zachwaszczenia łanu mieszanek łubinu wąskolistnego z owsem. Mniejszą masę chwastów odnotowano w łanie mieszanek zbieranych w fazie kwitnienia łubinu wąskolistnego niż w fazie płaskiego zielonego strąka łubinu wąskolistnego. Również Bojarczuk i wsp. (2013), Wojciechowski i wsp. (2013) oraz Staniak i wsp. (2014) odnotowali mniejszą masę chwastów w łanie mieszanek strączkowo-zbożowych zebranych we wcześniejszych fazach rozwojowych. W badaniach własnych wykazano interakcję, z której wynika, że najmniejszą świeżą i suchą masę chwastów odnotowano w łanie owsa uprawianego w siewie czystym zebranego $\mathrm{z}$ fazie kwitnienia łubinu wąskolistnego, a największą $\mathrm{w}$ łanie łubinu wąskolistnego uprawianego $\mathrm{w}$ siewie czystym zebranego $\mathrm{w}$ fazie płaskiego zielonego strąka.

Analiza statystyczna wykazała istotny wpływ badanych czynników doświadczenia i ich współdziałania na liczbę chwastów (tab. 3). Największą liczbę chwastów odnotowano $\mathrm{w}$ łanie łubinu wąskolistnego uprawianego w siewie czystym, a najmniejszą w owsie uprawianym w siewie czystym. Jest to zbieżne $\mathrm{z}$ wynikami badań Buraczyńskiej (2009) oraz Wojciechowskiego i wsp. (2013). W zrealizowanym eksperymencie liczba chwastów w łanie mieszanek łubinu wąskolistnego $\mathrm{z}$ owsem była istotnie 
Tabela 3. Liczba chwastów w łanie mieszanek łubinu waskolistnego z owsem (średnie z lat 2009-2011) [szt./ $\mathrm{m}^{2}$ ]

Table 3. The number of weeds in the mixtures of blue lupine and oat (average of the years 2009-2011) [pcs $\left./ \mathrm{m}^{2}\right]$

\begin{tabular}{|c|c|c|c|}
\hline \multirow[b]{2}{*}{$\begin{array}{l}\text { Udział komponentów w mieszance } \\
\text { The share of components } \\
\text { in the mixture }\end{array}$} & \multicolumn{2}{|c|}{ Termin zbioru - The harvest date } & \multirow[b]{2}{*}{$\begin{array}{l}\text { Średnie } \\
\text { Means }\end{array}$} \\
\hline & $\begin{array}{l}\text { faza kwitnienia łubinu wąskolistnego } \\
\text { flowering stage of blue lupine }\end{array}$ & $\begin{array}{c}\text { faza płaskiego zielonego strąka } \\
\text { łubinu wąskolistnego } \\
\text { flat green pod stage of blue lupine }\end{array}$ & \\
\hline $\begin{array}{l}\text { Łubin wąskolistny } 100 \% \\
\text { Blue lupine } 100 \%\end{array}$ & 36 & 42 & 39 \\
\hline Owies $100 \%$ - Oat $100 \%$ & 15 & 19 & 17 \\
\hline $\begin{array}{l}\text { Łubin wąskolistny } 75 \%+\text { owies } 25 \% \\
\text { Blue lupine } 75 \%+\text { oat } 25 \%\end{array}$ & 30 & 33 & 32 \\
\hline $\begin{array}{l}\text { Łubin wąskolistny } 50 \%+\text { owies } 50 \% \\
\text { Blue lupine } 50 \%+\text { oat } 50 \%\end{array}$ & 24 & 27 & 26 \\
\hline $\begin{array}{l}\text { Lubin wąskolistny } 25 \%+\text { owies } 75 \% \\
\text { Blue lupine } 25 \%+\text { oat } 75 \%\end{array}$ & 22 & 24 & 23 \\
\hline Średnie - Means & 25 & 29 & - \\
\hline \multicolumn{4}{|l|}{ NIR $(0,05)-\operatorname{LSD}(0.05)$} \\
\hline \multicolumn{3}{|c|}{ Udział komponentów w mieszance - The share of components in the mixture } & 3 \\
\hline \multicolumn{3}{|c|}{ Termin zbioru - The harvest date } & 2 \\
\hline \multicolumn{3}{|l|}{ Interakcja - Interaction } & 5 \\
\hline
\end{tabular}

Tabela 4. Plon świeżej masy mieszanek łubinu wąskolistnego z owsem (średnie z lat 2009-2011) [t/ha]

Table 4. Yield of fresh green matter of the mixtures of blue lupine and oat (average of the years 2009-2011) [t/ha]

\begin{tabular}{|c|c|c|c|}
\hline \multirow[b]{2}{*}{$\begin{array}{l}\text { Udział komponentów w mieszance } \\
\text { The share of components } \\
\text { in the mixture }\end{array}$} & \multicolumn{2}{|c|}{ Termin zbioru - The harvest date } & \multirow[b]{2}{*}{$\begin{array}{l}\text { Średnie } \\
\text { Means }\end{array}$} \\
\hline & $\begin{array}{l}\text { faza kwitnienia łubinu wąskolistnego } \\
\text { flowering stage of blue lupine }\end{array}$ & $\begin{array}{l}\text { faza płaskiego zielonego strąka } \\
\text { łubinu wąskolistnego } \\
\text { flat green pod stage of blue lupine }\end{array}$ & \\
\hline $\begin{array}{l}\text { Łubin wąskolistny } 100 \% \\
\text { Blue lupine } 100 \%\end{array}$ & 23,5 & 36,2 & 29,8 \\
\hline Owies $100 \%$ - Oat $100 \%$ & 29,8 & 42,1 & 35,8 \\
\hline $\begin{array}{l}\text { Łubin wąskolistny } 75 \%+\text { owies } 25 \% \\
\text { Blue lupine } 75 \%+\text { oat } 25 \%\end{array}$ & 27,4 & 36,1 & 31,7 \\
\hline $\begin{array}{l}\text { Łubin wąskolistny } 50 \%+\text { owies } 50 \% \\
\text { Blue lupine } 50 \%+\text { oat } 50 \%\end{array}$ & 34,8 & 44,2 & 39,5 \\
\hline $\begin{array}{l}\text { Łubin wąskolistny } 25 \%+\text { owies } 75 \% \\
\text { Blue lupine } 25 \%+\text { oat } 75 \%\end{array}$ & 32,0 & 40,6 & 36,3 \\
\hline Średnie - Means & 29,5 & 39,8 & - \\
\hline \multicolumn{4}{|l|}{ NIR $(0,05)-\operatorname{LSD}(0.05)$} \\
\hline \multicolumn{3}{|c|}{ Udział komponentów w mieszance - The share of components in the mixture } & 2,5 \\
\hline \multicolumn{3}{|c|}{ Termin zbioru - The harvest date } & 1,3 \\
\hline \multicolumn{3}{|l|}{ Interakcja - Interaction } & 2,9 \\
\hline
\end{tabular}

mniejsza od liczby chwastów w łanie łubinu wąskolistnego uprawianego w siewie czystym. Zmniejszenie udziału łubinu wąskolistnego w mieszance, a zwiększenie owsa powodowało istotny spadek liczby chwastów. Zdaniem Parylak i wsp. (2006), Buczka i wsp. (2007) oraz Buraczyńskiej (2009) siewy mieszane mogą wpływać na redukcję liczby chwastów. W omawianym doświadczeniu termin zbioru również istotnie modyfikował liczbę chwastów. Mniej chwastów odnotowano w łanie mieszanek łubinu wąskolistnego $\mathrm{z}$ owsem zebranych $\mathrm{w}$ fazie kwitnienia łubinu wąskolistnego niż w fazie płaskiego zielonego strąka. Podobną zależność stwierdzili Bojarczuk i wsp. (2013) oraz Wojciechowski i wsp. (2013). W ba- daniach własnych wykazano współdziałanie badanych czynników, z którego wynika, że najmniejszą liczbę chwastów odnotowano w łanie owsa uprawianego w siewie czystym zebranego zarówno w fazie kwitnienia łubinu wąskolistnego, jak i w fazie płaskiego zielonego strąka, a największą $\mathrm{w}$ łanie łubinu wąskolistnego uprawianego $\mathrm{w}$ siewie czystym zebranego $\mathrm{w}$ fazie płaskiego zielonego strąka.

Plon świeżej masy mieszanek łubinu wąskolistnego $\mathrm{z}$ owsem był istotnie różnicowany przez badane czynniki doświadczenia i ich interakcję (tab. 4). Największy plon świeżej masy otrzymano z mieszanki łubinu wąskolistnego z owsem o udziale komponentów 50\% + 50\%. Zdaniem 
Idziaka i Michalskiego (2003), Buraczyńskiej i Ceglarka (2009), Wojciechowskiego i wsp. (2013) oraz Bojarczuka i wsp. (2014) zasiewy mieszane plonują lepiej niż siewy czyste, gdyż w większym stopniu wykorzystują zmienne warunki siedliska. W badaniach własnych plon świeżej masy pozostałych mieszanek oraz owsa i łubinu wąskolistnego był istotnie mniejszy. Termin zbioru także istotnie różnicował plon świeżej masy mieszanek łubinu wąskolistnego $\mathrm{z}$ owsem. Większy plon zebrano $\mathrm{z}$ mieszanek łubinu wąskolistnego $\mathrm{z}$ owsem zebranych $\mathrm{w}$ fazie płaskiego zielonego strąka łubinu wąskolistnego. Również w badaniach Borowieckiego i Księżaka (2000), Wojciechowskiego i wsp. (2013) oraz Bojarczuka i wsp. (2014) mieszanki strączkowo-zbożowe zebrane w późniejszej fazie rozwojowej wytworzyły więcej biomasy. W omawianym doświadczeniu wykazano współdziałanie badanych czynników, z którego wynika, że największy plon świeżej masy otrzymano $\mathrm{z}$ mieszanki łubinu wąskolistnego z owsem o udziale komponentów 50\% + 50\% oraz z owsa uprawianego $\mathrm{w}$ siewie czystym zebranych $\mathrm{w}$ fazie płaskiego zielonego strąka łubinu wąskolistnego, a najmniejszy $\mathrm{z}$ łubinu wąskolistnego uprawianego w siewie czystym zebranego w fazie kwitnienia łubinu wąskolistnego.

\section{Wnioski / Conclusions}

1. Mieszanki łubinu wąskolistnego $\mathrm{z}$ owsem charakteryzowały się mniejszym zachwaszczeniem niż łubin wąskolistny uprawiany w siewie czystym.

2. Mniejszą masę i liczbę chwastów odnotowano w mieszankach zebranych $\mathrm{w}$ fazie kwitnienia niż $\mathrm{w}$ fazie płaskiego zielonego strąka łubinu wąskolistnego.

3. Największy plon świeżej masy otrzymano z mieszanki łubinu wąskolistnego z owsem o udziale komponentów $50 \%+50 \%$ oraz $\mathrm{z}$ owsa uprawianego w siewie czystym zebranych $\mathrm{w}$ fazie płaskiego zielonego strąka łubinu wąskolistnego.

\section{Literatura / References}

Bojarczuk J., Księżak J., Staniak M. 2013. Ocena zachwaszczenia mieszanek grochu siewnego z pszenicą jarą uprawianych w systemie ekologicznym. Journal of Research and Applications in Agricultural Engineering 58 (3): 33-40.

Bojarczuk J., Księżak J., Staniak M. 2014. Evaluation of yielding of oat-pea mixtures cultivated in organic farming. Journal Research and Applications in Agricultural Engineering 59 (3): 12-17.

Borowiecki J., Księżak J. 2000. Rośliny strączkowe w mieszankach ze zbożami w produkcji pasz. Postępy Nauk Rolniczych 2: 89-100.

Buczek J., Tobiasz-Salach R., Bobrecka-Jamro D. 2007. Ocena plonowania i odchwaszczającego działania jarych mieszanek zbożowych. Zeszyty Problemowe Postępów Nauk Rolniczych 516: 11-18.

Buraczyńska D. 2009. Zachwaszczenie mieszanek strączkowo-zbożowych przy zróżnicowanym składzie ilościowo-jakościowym. [Weed infestation of legume-ceral mixtures associated with different quantitative and qualitative composition]. Progress in Plant Protection/Postępy w Ochronie Roślin 49 (2): 779-783.

Buraczyńska D., Ceglarek F. 2009. Plon i skład chemiczny mieszanek strączkowo-zbożowych. Fragmenta Agronomica 26 (3): 15-24.

Christensen S. 1995. Weed suppression ability of spring barley varieties. Weed Research 35 (4): 241-247.

Creamer N.G., Bennett M.A., Stinner B.R., Regnier E.E. 1996. Mechanism of weed suppression in cover crop-based production systems. Hort Science 31 (3): 410-413.

Idziak R., Michalski T. 2003. Zachwaszczenie i plonowanie mieszanek jęczmienia jarego i owsa przy różnym udziale obu komponentów w zasiewie. Zeszyty Problemowe Postępów Nauk Rolniczych 490: 99-104.

Parylak D., Zawieja J., Jędruszczak M., Stupnicka-Rodzynkiewicz E., Dąbkowska T., Snarska K. 2006. Wykorzystanie zasiewów mieszanych, właściwości odmian lub zjawiska allelopatii w ograniczaniu zachwaszczenia. [Use of the mixed crops, cultivar properties or allelopathy in weed control]. Progress in Plant Protection/Postępy w Ochronie Roślin 46 (1): 33-44.

Sobkowicz P., Podgórska-Lesiak M. 2007. Zmiany w zachwaszczeniu zasiewów czystych i mieszanek dwóch odmian grochu $\mathrm{z}$ jęczmieniem pod wpływem nawożenia azotowego. [Changes in weed infestation in pure stands and mixtures of two pea cultivars with barley affected by nitrogen fertilization]. Progress in Plant Protection/Postępy w Ochronie Roślin 47 (3): 271-275.

Staniak M., Bojarczuk J., Księżak J. 2014. The assessment of weed infestation of oats-peas mixtures grown in organic farm. Journal of Research and Applications in Agricultural Enginering 59 (4): 83-88.

Wanic M., Nowicki J., Kurowski T.P. 2004. Zachwaszczenie oraz stan zdrowotny jęczmienia jarego i owsa uprawianych w mieszance i siewach jednogatunkowych Cz. I. Zachwaszczenie roślin. [Weed occurrence and sanitary state of spring barley and oat cultivated in a mixture and single-species stand Part I. Weed infestigation]. Progress in Plant Protection/Postępy w Ochronie Roślin 44 (2): $1191-1193$.

Wojciechowski W., Kozak M., Białkowska M., Ćwiertniewska M. 2013. Wpływ mieszanek strączkowo-zbożowych na zachwaszczenie łanu. [Effect of legume-cereal mixtures for weed infestation]. Progress in Plant Protection/Postępy w Ochronie Roślin 53 (1): $110-114$. 